\title{
The Impact of Computer-assisted Language Learning Training on Teachers' Practices
}

\author{
Mohsen Hedayati \\ Faculty of Education, University of Tasmania, Launceston, Australia \\ Bronwyn Reynolds \\ Faculty of Education, University of Tasmania, Launceston, Australia \\ Andy Bown \\ Faculty of Education, University of Tasmania, Launceston, Australia
}

\begin{abstract}
This study investigated and identified the common computer-assisted language learning (CALL) teacher training types in the Iranian private language schools (PLSs), and their effectiveness in shaping and encouraging teachers' use of new technologies. An exploratory mixed method approach was employed, and a total of 86 Iranian EFL (English as a foreign language) teachers participated in this study. The results indicated that teachers were primarily self-trained, in the absence of comprehensive CALL training provided by either PLSs or teacher training courses offered at university level. It was concluded that self-training had resulted in subsequent sporadic and non-systematic use of CALL by teachers.
\end{abstract}

Index Terms - language teacher training, computer-assisted language learning, English as a foreign language, professional development

\section{INTRODUCTION}

The utilization of new technologies in language teaching and learning, generally known as computer-assisted language learning (CALL), is a relatively new phenomenon in the Iranian private language schools (PLSs). Despite its newness, CALL has attracted the attention of Iranian English as a Foreign Language (EFL) teachers and they have expressed positive attitudes towards integrating new technologies into their teaching practices (Fatemi Jahromi \& Salimi, 2013; Zare-Ee, 2011). Teachers' positive attitudes, however, may not necessarily and automatically result in the effective implementation of CALL (Godwin-Jones, 2015; Peeraer \& Petegram, 2010). Research has consistently shown that different factors discourage teachers from stepping outside their comfort zone and embracing the affordances provided by 21 st century technologies. For instance, in Hedayati and Marandi's (2014) study, three main barriers to the integration of new technologies were identified: teacher constraints (e.g. lack of CALL preparation), facility constraints (e.g. limited access to technology), and learner constraint (e.g. insufficient digital literacy).

While availability of new technologies (Chun, 2016) and learner characteristics (Lee, 2016) are of considerable importance, it is widely agreed that teachers perform the central role in effective integration of the technological tools and affect "the outcomes of CALL through their instructions, scaffolding, feedback and responses" (Arnold \& Ducate, 2015, p. 1). Given this, over the past two decades, a considerable amount of literature has been published on CALL teacher education (Cutrim Schmid \& Hegelheimer, 2014; Egbert, Paulus, \& Nakamichi, 2002; McNeil, 2013; Wildner, 2013) and the journal of Language Teaching \& Technology (Vol. 19, 2015), for instance, allocated a special issue to teacher education and CALL. Recent evidence suggests that CALL teacher training positively contributes to teachers' more effective use of new technologies (Kozlova \& Priven, 2015; Tai, 2015; Wach, 2015). Debate, however, continues about the modality, length and nature of the CALL training that teachers need to receive (Chao, 2015). In addition, research indicates that context is an important factor to be considered in CALL instruction (Gonzalez \& Louis, 2013, Hong, 2010).

During the last decade, whilst CALL has been acclaimed by Iranian EFL teachers, it seems that limited attention has been given to CALL teacher training in this specific context. What is not yet clear is the type and nature of training that EFL teachers generally receive, and how this training affects the implementation of CALL and its outcomes. In view of this, the purpose of this study was to explore the current CALL teacher training system in Iran, and to investigate its impact on EFL teachers' use of new technologies.

\section{LITERATURE REVIEW}

The integration of new technologies, such as the Internet, Web 2.0, wikis, blogs, podcasts and other ever-changing digital facilities and gadgets, into second/foreign language teaching and learning requires a comprehensive understanding of the educational context and the factors that may affect the planning, process and outcome of this 
synergy (Gonzalez \& Louis, 2013). Adopting a simple plug-and-play approach to computers has proven to be ineffective (Cuban, 2001). Hubbard and Levy (2006) stated that the increase in the availability of the Internet and computers in schools and home settings has resulted in the more widespread use of technology in second or foreign language teaching and learning, and as a consequence, teachers feel incompetent and ineffectual if they are not reasonably familiar with CALL.

\section{A. The Role of the Teacher}

While a large volume of published studies have reported the effectiveness of using new technologies in second/foreign language teaching and learning (e.g., Blake, 2013; Golonka, Bowles, Frank, Richardson, \& Freynik, 2014; Lamy \& Hampel, 2007), some researchers have warned that seeing technology as a panacea is a misleading idea (Chun, 2016). To achieve effective and successful implementation of CALL, one factor, among others, has been reported to be extremely critical, and that is the role of the teacher (Arnold \& Ducate, 2015; Godwin-Jones, 2016; Guichon \& Hauck, 2011; Hubbard, 2008; Little, 2007; Zhao \& Cziko, 2001). Godwin-Jones (2016) wrote that "language teachers play a vital role in both encouraging our students to explore extramural learning activities and finding ways to assist and assess the learning achieved" (p. 6). Little (2007) asserted that teachers could help students to foster learner autonomy by guiding them throughout the learning process and monitoring and evaluating their progress. O'Dowd (2015) purported that teachers in telecollaborative exchanges, where students from different cultural backgrounds engage in online communication, not only need to have ICT knowledge, but also need to develop competence in multiliteracy and intercultural communication to successfully mediate the communication among participants. The role of teacher is critical not only in CALL, but also in a broad sense of every educational context. Kumaravadivelu (2002) emphasized the importance of the teacher's role by using a metaphor. He considered theorists as play writers and teachers as actors on the stage. Theorists and curriculum developers design and construct knowledge behind the scene, whereas, teachers understand and transfer that knowledge on the stage. With respect, if the actor cannot act successfully on the stage in front of the audience, then all the behind the scene plans will be negated.

\section{B. The Use of Technology by Teachers}

Early in the 21st century, when the implementation of CALL was accelerating, Zhao and Cziko (2001) recognised an ironic contradiction in the process of integrating technology into education. They argued that although the benefits of technology in education have been reported widely, most teachers do not use it frequently in their teaching practices. Research on teachers' use of technology reports different reasons for teachers not using technology. For example, an absence of appropriate training, traditional pedagogical attitudes, teachers' personal attitudes toward technology, resistance to change, time management issues, low technical and administrative support, and a lack of digital literacy (Egbert et al., 2002; Mumtaz, 2000). The successful implementation of technology, however, in education, and particularly teaching, depends on how teachers perceive and implement technology (Motteram, Slaouti, \& Onat-Stelma, 2013; Mumtaz, 2000). Hence, acceptance or rejection of the use of technology in teaching practices directly and indirectly affects the teacher's role in the classroom environment. Teachers aspiring to use technology should prepare themselves to play different roles from teachers who are following traditional methods. As Hubbard and Levy's (2006) propose, CALL teacher roles can be associated with being a practitioner, developer, researcher, and/or trainer.

\section{CALL and Teacher Training}

CALL teacher training/education has been identified as a major tool for encouraging and boosting technology use among language teachers (Wach, 2015). Chapelle (2006) asserted that teachers in CALL should gain the related literacies and skills to be able to choose, use, and sometimes ignore technology for their learners. Despite this, Kessler (2006) purported that many of the TESOL masters programs lacked formal CALL training, and graduates were reported to be dissatisfied with the technology-related lessons they received. He also observed that training was mainly focused on either digital literacy or software features.

Globally, CALL teacher training is being delivered in/to different structures and degrees, according to contextspecific educational conditions and teacher characteristics. This continuum ranges from short-term CALL workshops (e.g., Liu \& Kleinsasser, 2015; O’Dowd, 2015) to university courses in CALL (e.g., Shin, 2015). One major categorization here is formal versus informal training. This is closely related to whether teachers are pre-service or inservice when they receive their training. Arnold and Ducate (2015), for example, believed that informal training is more effective in in-service contexts. Situated learning is another method of training that has been proved to be effective in CALL contexts (Egbert, 2006; McNeil, 2013; Wang, Chen, \& Levy, 2010). There is an ongoing discussion regarding the modality, duration and content of CALL teacher training (Arnold \& Ducate, 2015). Egbert et al. (2002) investigated how teachers learn about CALL and how their training impacts their teaching practices. The results of their mixedmethod study revealed that a single course on CALL may result in learning about the available technology but not necessarily to its use. They suggested that coursework should be situated in authentic learning contexts where teachers have the opportunity to practice, apply technologies and observe evidence of student improvement.

Dooly (2009) reported on the results of a collaborative CALL teacher training project where teachers could learn from each other via dialogic network-based interactions. She found that "novice (or soon to be) teachers are worried about how they will deal with their students when they are on their own in their classroom. These worries and doubts 
need to be acknowledged and given sufficient time and attention" (p. 365). Hampel (2009) suggested that an effective CALL teacher training program should contain the following components:

- mix of pre-service and in-service training to develop a range of skills and maintain and update them;

- tools training and technical support;

- hands-on pedagogical training; putting teachers in the role of students interacting with one another and collaborating on a task;

- guidance with task design that creates the right conditions for collaboration and makes best use of the tools employed;

- modelling what is expected of teachers (e.g. careful scaffolding of tasks, precise task instructions, moderation);

- activity banks with interactive tasks for tutor use;

- pedagogical support;

- self-reflection and feedback; and

- space for sharing experience(p. 48).

In her study, Hampel (2009) also discovered that there are a number of institutional factors that can influence the success of the training programs. These factors include "the necessity of tailoring training to specific institutional needs (e.g., in terms of tools), the fit of pedagogical approaches and institutional set-up, and the need to regulate and monitor tutor workload" (p. 49).

\section{CALL in the Iranian Context}

While CALL is recognized as a standard and expected part of a language teaching and learning curriculum in some developed countries (Kessler, 2006), it is still a relatively new approach in others, such as Iran. Limited access to technological tools, insufficient digital literacy among language learners and teachers, and a lack of CALL instructional design skills are considered factors that have resulted in the inadequate implementation of CALL in Iranian schools (Hedayati \& Marandi, 2014). Despite its newness, CALL has attracted Iranian EFL teachers' attention and they have expressed positive attitudes towards integrating new technologies into their teaching practices (Fatemi Jahromi \& Salimi, 2013; Zare-Ee, 2011). In addition, a considerable amount of research has been conducted into the application of CALL with Iranian EFL learners (Foomani \& Hedayati; 2016; Ghaemi \& Ebrahimi; 2015; Hedayati \& Foomani, 2015; Khodaparast \& Ghafournia, 2015). To date, however, there has been little discussion about CALL teacher training/education in the Iranian context, and how training impacts on teachers' implementation of CALL. Hence, this study was conducted to investigate and identify the CALL teacher training status quo in Iran, and its impact on EFL teachers' use of new technologies.

\section{METHOD}

Following an exploratory mixed method design, this study began by interviewing eight EFL teachers. Afterwards, the quantitative phase was conducted by surveying 78 EFL teachers. It was intended that broad information gathering methods would help to address unanticipated topics (Patton, 2002). Only teachers employed in private language schools (PLSs) were invited to participate in this study, as the majority of language learners (especially adult learners) in Iran take courses in PLSs to learn a foreign language, such as English, in a communicative and more flexible way (Khoshsima \& Toroujeni, 2017). While language units are embedded in the national curriculum of Iran, and are offered in public schools, the lack of competent language teachers and limited class hours in these contexts motivates language learners to seek better language learning experiences in PLSs (Mohammadian Haghighi, \& Norton, 2017).

EFL teachers in four different PLCs in a northern city of Iran, Zanjan, were invited to participate in this study. Purposeful sampling (Cohen, Manion, \& Morrison, 2007) was engaged and all the participants needed to be Iranian, EFL teachers, employed in a PLS and have a basic knowledge of ICT. The four schools were equipped with computers, data projectors, and the Internet. Interviews were conducted face-to-face and participants were asked open-ended questions. The questions were designed and developed prior to the interview, but the researcher explored further related questions where more illustrations and probing were needed and/or more data could be obtained. As the teachers were all proficient users of the English language, the interviews were conducted in English, and no translation was required. To protect the participants' identities, pseudonyms (Arash, Sima, Navid, Maryam, Reza, Ava, Amir and Mahin) have been used. Table 1 illustrates the demographics of the participants in the qualitative phase.

TABLE 1

INTERVIEW PARTICIPANT DEMOGRAPHICS

\begin{tabular}{lllll}
\hline Pseudo-names & Gender & Age Range & Teaching Experience (Years) & Qualification \\
\hline Arash & Male & $31-40$ & 13 & PhD in TEFL (teaching English as a foreign language) \\
Sima & Female & $18-20$ & 2 & B.A Student in IT (information \& technology) \\
Maryam & Female & $21-30$ & 5 & M.A. Student in TEFL \\
Ava & Female & $21-30$ & 2 & B.A Student in English Language Translation \\
Navid & Male & $21-30$ & 6 & M.A student in TEFL \\
Reza & Male & $21-30$ & 9 & B.A in Psychology \\
Mahin & Female & $21-30$ & 8 & M.A. in TEFL \\
Amir & Male & $21-30$ & 2 & B.A student in TEFL \\
\hline
\end{tabular}


Participants responded to the following focus questions:

- What type of technological tools do you use in your teaching?

-What do you use technological tools for in your teaching?

- Please describe a lesson were you implemented CALL.

- What type of CALL training have you received? Please explain.

- How does school provide you with CALL training and tools?

- How did you receive training to help you implement CALL?

- How do you share your CALL knowledge and skills with colleagues?

After conducting the interviews, 150 invitations were sent out to potential participants via LinkedIn, and 78 (44 females; 34 males) of these responded to the survey, which equated to a response rate of 52\%. The reason for recruiting participants through LinkedIn was threefold. First, it was convenient to search for and identify teachers who met the eligibility criteria required for this study. When a teacher uses LinkedIn, the presumption is that she/he is familiar with the Internet, web browsing, social media and similar affordances of ICT. Secondly, the survey implemented in this study was online, and it was appropriate to send the link to the participants through LinkedIn's messaging feature. Finally, this medium provided the opportunity to reach subjects from 22 different cities all around Iran, a variation which in turn enhanced the generalizability of the findings to the target population. Table 2 illustrates the demographics of the participants in the quantitative phases of the study.

TABLE 2

SURVEY PARTICIPANT DEMOGRAPHICS

\begin{tabular}{llll}
\hline & categories & $\mathrm{n}$ & $\%$ \\
\hline Gender & Female & 49 & 62.8 \\
& Male & 29 & 37.2 \\
Age & $18-20$ & 2 & 2.6 \\
& $21-25$ & 12 & 15.4 \\
& $26-30$ & 25 & 32.1 \\
& $31-35$ & 25 & 32.1 \\
& $36-40$ & 7 & 9.0 \\
Professional & Above 40 & 7 & 9.0 \\
language-related & None & 6 & 7.7 \\
degree & Bachelors & 12 & 15.4 \\
& Masters & 44 & 56.4 \\
\hline Teaching experience & PhD & 16 & 20.5 \\
(years) & $1-3$ & 15 & 19.2 \\
& $4-6$ & 30 & 38.5 \\
& $7-9$ & 9 & 11.5 \\
& 10 and more & 24 & 30.8 \\
\hline
\end{tabular}

The survey was composed of 17 multiple-choice questions, including demographic information, teachers' CALL competence (through self-assessment) and the types of CALL training they had received. The survey was developed, designed and implemented on the Qualtrics platform (www.qualtrics.com). A link to the survey was sent to the participants through the LinkedIn messaging system.

The collected data were analyzed both qualitatively and quantitatively. Qualitative data were analyzed and interpreted using both thematic analysis (Braun \& Clarke, 2006) and axial coding (Corbin \& Strauss, 2008) methods. For the quantitative data, descriptive and correlational analyses were employed using SPSS.

\section{RESULTS}

\section{A. Qualitative Data}

1. Technology use

In response to the first question, what type of technological tools do you use in your teaching, teachers identified various tools. The most commonly used technologies included CD players, personal computers, TV screens, and, in some cases, data projectors and smart phones. Two of the eight teachers reported using online resources, with one using the Telegram social networking tool and the other employing the Edmodo learning management system. Teachers' motivations for using technology were categorized into three groups: 1) delivery of audio-visual materials in the target language, 2) using technology as a search engine, and 3) sharing of resources, along with feedback. In the first category, CD players were reported to be widely used for playing audio tracks for listening exercises. Three teachers, however, preferred to use their laptops and smartphones instead on a regular basis. They used TV screens and data projectors to display visual materials (e.g. pictures and videos) related to the content of the textbook. Teachers expressed their inclination to use current technologies, rather than outdated tools like CD-players. Arash, for instance, mentioned that he played supplementary videos for each lesson in the core textbook on a big screen using data projector. Maryam noted that playing audio files for listening exercises was an unavoidable part of teaching. She reported playing audio files on her smartphone, rather than CD player, as she thought the latter was outdated and time-consuming. 
In relation to the second category, teachers reported their use of new technologies for searching purposes, using either digital dictionaries or online search engines. Sima stated that she browsed the Internet to find relevant pictures and videos for the topic of every lesson, and displayed them on her laptop or data projector. She also encouraged her students to use their smartphones to browse online resources to find answers for the questions raised in the class. She believed that it was a fun way to engage students in discovery learning. Reza perceived technology as a tool, which could help teachers compensate for the lack of content knowledge when teaching certain points. He reported regular use of dictionary applications on his smartphone to look for the meanings of vocabulary items.

In terms of the third category, two of the teachers reported using social media and learning management systems. Ava created an online group using the Telegram social media application to maintain her connection with students after classroom hours, and she posted extracurricular multimedia materials, relevant to the textbook lessons. In this group, students were encouraged to share their materials and comments. In contrast, used the Edmodo learning management system (LMS) to mark students' assignments and provide them with feedback. Students were expected to upload their assignments or questions to Edmodo, and their teacher, Navid, provided feedback via the same platform. Navid mentioned that Edmodo allowed his students to upload various modes of multimedia, appropriate to their learning styles and preferences. Similarly, he stated that he could provide them with feedback, in not only text format, but also other multimedia files such as audio or video.

2. CALL training

A majority of the interviewees (6) reported that they had not received any type of CALL training, either during their university studies, or in their workplace. These teachers were reported to be self-trained in CALL; except two of them, Navid and Ava, who had the experience of attending CALL workshops. Three categories of reasons for teachers' following a self-training method were identified: 1) lack of CALL training provided by the PLS, 2) lack of CALL units in university language teacher training courses, and 3) lack of peer-learning among teachers in PLSs. Mahin, who had been teaching English for eight years, stated that:

We have training sessions in our school, but it doesn't cover any topic specifically related to CALL. I use Internet and digital dictionaries in my classes, based on what I have learnt myself.... Most the time I try a tool and see if it is useful or I need to try another one.

Amir, another teacher with two years of teaching experience also said that:

I like to be a teacher who is aware of new technologies, [be]cause I think this is what my students expect from me. There are many Internet [online] sources that I can get hints from them. I like to discuss about CALL with my colleagues and try to get new ideas, but this doesn't happen very often. The school doesn't demand us to use any specific technology, but I personally like to use it.

This was a recurrent theme in the interviews; a sense amongst interviewees that there is no CALL training provided by the PLSs, and in most cases, no obligation from schools to use new technologies, except outdated ones like CDplayers. Another emerging theme was the lack of CALL training in university TESOL courses. Arash, for example, who had a PhD in TEFL, had done his bachelors and masters in English language teaching as well. He said that, during all those years of studying TEFL, he was never offered a course or unit on CALL at university. He explained:

I think the content of TEFL courses at university need to be modified, and include lessons on CALL to prepare teachers to use technologies effectively.... Language teaching context is different form 10 years ago, and it keeps changing. So, I think the content of teacher training [at university] should be up-to-date as well and address the needs of teachers and students.

Teachers reported a lack of pedagogical competence in identifying/designing and implementing technologyintegrated tasks, which could help them achieve the course objectives. Technology use was mainly restricted to simple tools such as CD-players, which, as stated by Navid, are considered as outdated technologies in today's world. As Mahin explained, a lack of instructional design knowledge for the implementation of CALL left teachers puzzled about answering what, how, when and where questions regarding the use of new technologies. They found it difficult to choose the appropriate tool which would be relevant and attractive for students. Amir, an early career teacher, said that:

A big challenge for me is selecting appropriate tool.... Another problem is using that technology regularly. Because I use for example Internet browsing spontaneously at the times that I think it is helpful to use.... I can say I don't follow a specific plan for integration of technology.

Yet, Navid, who had the experience of attending a CALL workshop, perceived this training type as effective and informative. He explained:

I recently attended a two-hour workshop about the Edmodo website. I think it was very informative. After this workshop, I decided to transfer part of my teaching into this online environment. Before attending this workshop I had no idea about learning management systems.

While Navid was satisfied with the content and structure of the workshop, he highlighted the existence of a few problems:

One problem is that these kind of workshops are sometimes expensive to register and attend.... I myself decided to attend this workshop, so I received no financial support from school. The other problem is that when I decide to apply Edmodo in my classes, I receive no support or appreciation from school, which I think is demotivating sometimes. 
The findings from the interviews, together with the reflections from related literature, formed the content of the survey for the quantitative phase. The survey was conducted to examine the qualitative findings in a broader context, to increase the generalizability of the results.

\section{B. Quantitative Data}

Of the study population $(n=78), 62.8 \%$ were female and $37.2 \%$ were male teachers. Participants were recruited from 22 different cities around Iran, including major cities such as Tehran, Tabriz, Mashhad and Isfahan. The majority of teachers aged between 26 and 35 (64.2\%) which indicates that EFL teachers in PLSs are relatively young. This accords with the earlier observation in Mohammadian Haghighi and Norton's (2017) study, which reported the youthful characteristics of Iranian EFL teachers in PLSs. Nearly all the participants $(92.3 \%)$ had language-related professional degrees, with more than half of them (56.4\%) holding a master's degree, followed by a PhD (20.5\%) and bachelors $(15.4 \%)$ degrees. These results indicate Iranian EFL teachers' desire to seek advanced teacher training courses at masters and PhD levels. A small minority of those surveyed, six teachers, indicated that they had no language related professional degrees, certificates or diplomas, which shows that teachers with no language-related qualifications are allowed to teach in PLSs, as long as they demonstrate an acceptable level of proficiency in the target language. More than two-thirds of the participants $(69.2 \%$ ) had degrees in English Language Teaching (ELT), and the remaining participants graduated in English Literature and English Language Translation subjects.

In response to the question about job status, 53 of the participants reported that they were part-time teachers (teaching for less than 30 hours per week), while the other 25 were full-time teachers (teaching for 30 hours per week or more). Job Status was defined based on the norms of working hours in Iran. There are three possible explanations for the popularity of part-time teaching among Iranian teachers. First, many of the teachers were simultaneously studying at university, and it leaves them with limited time available for working. Secondly, the salary of PLS teachers is relatively low compared to other professions, and teachers need to take other jobs to supplement their income. Finally, PLSs usually offer language classes in the evening to meet the needs of students, and accordingly, there are not many teaching opportunities during the morning or afternoon.

When participants were asked to self-assess their competence in implementing CALL on a scale from 0 (not confident at all) to 10 (highly confident), over half expressed having middling to nearly high $(\mathrm{Mean}=7.09, \mathrm{SD}=2.09$ ) confidence. A point-biserial correlation was run to determine the relationship between teachers' professional degree and their perceived CALL competence. Surprisingly, results showed that there was a weak negative relationship between these two variables $(\mathrm{rpb}=-.228, \mathrm{n}=78, \mathrm{p}=.048)$. This shows that higher professional degrees had not increased Iranian EFL teachers' confidence in using CALL. Likewise, no meaningful relationship was observed between the gender and CALL competence variables $(\mathrm{rpb}=-.082, \mathrm{n}=78, \mathrm{p}=.047)$. It should be noted, however, participants' competence in CALL was assessed based on their personal perceptions. In other words, assessing participants' CALL competence based on their practical practices may demonstrate different results.

The second section of the questionnaire required respondents to provide information about CALL teacher training. The first question asked about the type of CALL training that teachers had received, presenting them with 6 choices (adopted partly from Kessler, 2006). Respondents could choose more than one answer. Table 3 below summarizes the responses:

TABLE 3

CALL TRAINING THAT IRANIAN TEACHERS REPORTED HAVING RECEIVED

\begin{tabular}{lll}
\hline 1. I learnt CALL . . & $\mathrm{n}$ & $\%$ \\
\cline { 2 - 3 } on my own (for instance by browsing the net) & 55 & 70.5 \\
from my colleagues in school & 16 & 20.5 \\
by attending a workshop & 14 & 17.9 \\
by attending a training course organized by a language school & 5 & 6.4 \\
by undertaking a course at university & 13 & 16.7 \\
other & 9 & 11.5 \\
\hline
\end{tabular}

It can be seen from Table 3 that the majority of teachers $(70.5 \%)$ had learnt to use CALL on their own, or in other words, they were self-trained. Only five teachers reported having experience of learning CALL by attending a training course organized by PLSs. One-fifth of the participant population experienced learning how to use new technologies by interacting and sharing knowledge with other teachers. CALL workshops and courses at university, although not very common, were other resources for learning about the use of new technologies in language teaching. Many of the respondents who chose "other" also indicated examples of self-directed and peer learning; for instance, via using social networking tools and browsing the Internet for online resources.

To compare teachers' present CALL training with their preferred ways of learning CALL, teachers were asked how they preferred to learn CALL. The results showed a disparity between preferences and experiences, as shown in Table 4 below. 
TABLE 4

TEACHERS' PREFERRED WAY OF LEARNING CALL

\begin{tabular}{lll}
\hline 2. I prefer to learn CALL ... & $\mathrm{n}$ & $\%$ \\
\cline { 2 - 3 } on my own (for instance by browsing the net) & 19 & 24.4 \\
from my colleagues in school & 5 & 6.4 \\
by attending a workshop & 34 & 43.6 \\
by attending a training course organized by language school & 11 & 14.1 \\
by undertaking a course at university & 5 & 6.4 \\
other & 4 & 5.1 \\
\hline
\end{tabular}

As illustrated in Table 4, the majority of teachers (43.6\%) indicated that attending a workshop would be their first preference. Comparing this response rate to teachers' current CALL training through workshops (17.9\%), highlights the existence of a gap between teachers' current practices or opportunities and their preferences. The other striking difference was related to self-directed learning. While currently a majority of participants learn CALL on their own, the data show that only a quarter of them prefer to continue this way. When examining teachers' preferences, only five individuals chose undertaking a CALL course at university. Some respondents also indicated their preference for having more opportunities for learning CALL through attending a training course organized by a language school.

Table 5 below illustrates the succeeding questions in the survey, and participants' responses to them. Employing a top-2-box scoring method for interpretation of data, the majority of teachers reported that they are likely to share their knowledge. However, they reported less likelihood of this kind of cooperation among teachers in their PLSs. Teachers were motivated to learn CALL, irrespective of the availability/quality of technological tools in the PLS. Most of those surveyed believed that PLSs need to provide language teachers with CALL training. There was a moderate tendency toward the idea that early-career teachers are better at learning and adopting CALL. These findings are further discussed in the discussion section below.

TABLE 5

TEACHERS' RESPONSES TO QUESTIONS 3-7

\begin{tabular}{|c|c|c|c|c|c|c|c|c|c|c|}
\hline & \multicolumn{2}{|c|}{$\begin{array}{l}\text { extremely } \\
\text { likely }\end{array}$} & \multicolumn{2}{|c|}{$\begin{array}{l}\text { somewhat } \\
\text { likely }\end{array}$} & \multicolumn{2}{|c|}{$\begin{array}{l}\text { neither } \\
\text { likely nor } \\
\text { unlikely }\end{array}$} & \multicolumn{2}{|c|}{$\begin{array}{l}\text { somewhat } \\
\text { unlikely }\end{array}$} & \multicolumn{2}{|c|}{$\begin{array}{l}\text { extremely } \\
\text { unlikely }\end{array}$} \\
\hline & $\mathrm{n}$ & $\%$ & $\mathrm{n}$ & $\%$ & $\mathrm{n}$ & $\%$ & $\mathrm{n}$ & $\%$ & $\mathrm{n}$ & $\%$ \\
\hline $\begin{array}{l}\text { 3. I share my CALL knowledge and experience with my } \\
\text { colleagues at school. }\end{array}$ & 28 & 35.9 & 24 & 30.8 & 12 & 15.4 & 8 & 10.3 & 6 & 7.7 \\
\hline \multirow{2}{*}{$\begin{array}{l}\text { 4. In my school, teachers share their CALL knowledge } \\
\text { with each other. }\end{array}$} & 10 & 12.8 & 26 & 33.3 & 16 & 20.5 & 20 & 25.6 & 6 & 7.7 \\
\hline & \multicolumn{2}{|c|}{$\begin{array}{l}\text { strongly } \\
\text { agree }\end{array}$} & \multicolumn{2}{|c|}{$\begin{array}{l}\text { somewhat } \\
\text { agree }\end{array}$} & \multicolumn{2}{|c|}{$\begin{array}{l}\text { neither } \\
\text { agree nor } \\
\text { disagree }\end{array}$} & \multicolumn{2}{|c|}{$\begin{array}{l}\text { somewhat } \\
\text { disagree }\end{array}$} & \multicolumn{2}{|c|}{$\begin{array}{l}\text { strongly } \\
\text { disagree }\end{array}$} \\
\hline $\begin{array}{l}\text { 5. I am not motivated to learn CALL, because there is } \\
\text { not suitable technological infrastructure in my school. }\end{array}$ & 9 & 11.5 & 13 & 16.7 & 9 & 11.5 & 19 & 24.4 & 28 & 35.9 \\
\hline $\begin{array}{l}\text { 6. I think schools are responsible for training teachers } \\
\text { how to use CALL. }\end{array}$ & 45 & 57.7 & 24 & 30.8 & 4 & 5.1 & 5 & 6.4 & 0 & 0 \\
\hline $\begin{array}{l}\text { 7. Novice teachers are quicker in transferring into CALL } \\
\text { teachers. }\end{array}$ & 8 & 10.3 & 31 & 39.7 & 26 & 33.3 & 8 & 10.3 & 5 & 6.4 \\
\hline
\end{tabular}

\section{DISCUSSION}

The initial objective of the current research was to identify the prevalent CALL training types received by Iranian EFL teachers, and investigate how these training types affected teachers' practices. Prior studies have shown that training has various types and structures, ranging from short-term CALL workshops (Liu \& Kleinsasser, 2015; O’Dowd, 2015) to university courses in CALL (Shin, 2105). However, there are teachers who have expressed their willingness to learn CALL on their own (Kessler, 2006) or from colleagues (Egbert et al., 2002).

\section{A. CALL Teacher Training}

Consistent with the results of Kessler's (2006) research, the majority of respondents in this study, both qualitative and quantitative phases, reported they were self-trained in CALL. What is surprising is that, despite almost all of the participants in this study had English language related university certificates, they had not received specific training in how to implement CALL in their practices. This shows that TESOL courses in the Iranian universities, regardless of being bachelors or masters degrees, do not particularly train EFL teachers to become competent and efficient users of new technologies for pedagogical purposes. These results accord with earlier research in the Iranian context (Hedayati \& Marandi, 2014), and highlight the necessity for changes in the content of language teacher training courses at the university level (Hong, 2010). By comparing the responses to questions 1 and 2 in the survey, it was also recognized that, while a small number of teachers reported learning about CALL at university, this training type was not identified as their preferred way of learning CALL. This lack of interest, likewise, may be attributed to absence of solid CALL units in TESOL courses offered by universities. One of the interviewees stated that CALL was not taught as a separate 
unit, and this topic was introduced briefly by those professors in applied linguistics, who were personally interested in this subject area.

Another interviewee mentioned that the discussions they had about CALL at university were mostly theoretical, and no hands-on practice was offered. Considering these aspects, it seems unlikely that current university-level teacher training would prepare Iranian EFL teachers to use technology. Similar to Egbert, Paulus, and Nakamichi' (2002) findings, this kind of coursework and training "may lead to technology learning but not necessarily to its use" (p. 111). In a similar vein, Hubbard and Levy (2006) differentiated between CALL knowledge and CALL skill, where the first one is about what the teacher needs to know, and the latter explains what the teacher should be able to do. Given this, theory-based CALL instruction may increase teachers' CALL knowledge, however, gaining CALL skills requires undertaking hands-on lessons. Moreover, skill-based training can be tailored to teachers' context-specific needs to enhance effectiveness. O'Dowd (2015) stated that, "It is unrealistic to attempt to train educators in the intricacies of telecollaborative exchange through the simple transmission of facts and guidelines in instructor-driven set ups" (p. 77).

The findings of this study highlight the need for Iranian EFL teachers to gain relevant context-specific literacies and skills to use new technologies. According to governmental policy, for instance, some technologies (e.g., YouTube) are not allowed to be used in Iran. These kinds of restrictions are sometimes imposed by outsiders as well. For instance, the name of Iran is not even included in the registration forms of some popular global websites. Moreover, cultural, privacy and security concepts are different from those in western countries (Nia \& Marandi, 2014). A teacher who intends to use new technologies needs to be aware of these facts and factors. It seems that CALL teacher training at PLS level may be the best place for teachers to gain not only technological knowledge, but also knowledge of the context.

CALL teacher training was reported to be absent in PLSs also. As one of the teachers pointed out, PLSs provide training sessions for teachers, however, no CALL-specific content is included in these sessions. Moreover, schools do not urge or expect teachers to integrate technologies into their practices. Accordingly, teachers who implement CALL are not supported or encouraged by the school system. Conversely, as one of the participants stated, support from PLSs seems necessary to help teachers apply the skills they have learnt in the workshops or any other training environment. As Hubbard and Levy (2006) ask, "what are teachers able to do with the material they acquired in a CALL course once it is over? And what factors may explain individual differences in success with transferring CALL knowledge and skills to their own classrooms?" (p. 250). A number of teachers in this study chose training or workshops organized by PLSs as their preferred way of learning CALL. One key advantage of school-led workshops could be the delivery of contextspecific training, which is informed by the pedagogical and technological characteristics of that school, as well as the existing affordances and limitations.

Comparing the responses to Questions 1 and 2 reveals the existence of a gap between teachers' current received CALL training (i.e. self-training) and their preferred ways of learning CALL (i.e. attending workshop). While Kessler (2006) acknowledges teachers self-directed lifelong learning, he highlights the need for empowering this learning type with theories and principles of CALL, together with hands-on practices. This may justify why participants in this study reported limited and sporadic use of technologies in their practices, despite assessing themselves as relatively competent in implementing CALL. It is suggested that self-training, which is not accompanied by a sound understanding of CALL theories and foundations, leaves teachers unguided in various stages of CALL design, implementation and evaluation.

Another important finding was the lack of appropriate conditions for fostering cooperation and peer learning among teachers in PLSs. While over half of the teachers said they were likely to share their CALL knowledge and experience with colleagues, they reported that, in practice, not many teachers in their schools share their CALL knowledge with others. While this could be result of 'impression management' displayed by teachers to express their unselfish behavior, another possible explanation for this difference might be that, despite teachers' willingness to share their knowledge, PLSs are not successful in creating cooperative learning opportunities, or professional learning communities among teachers (Hord, 2009). Professional learning communities, which are based on constructivist learning theory, encourage teachers to bring their prior knowledge and experience to the new learning community, and perceive learning as a developmental process that requires being active and reflective (Burns, Menchaca, \& Dimock, 2002). Kozlova and Priven (2015) conducted a study where teacher trainees engaged in cloud-based collaborative learning to develop 3Dspecific teaching skills. Results showed that collaboration among teachers, by providing constant peer-evaluation and scaffolding, helped teachers to develop their skills effectively. In view of that, initiating this kind of collaborative and informal learning communities among Iranian EFL teachers could help them to enhance their CALL knowledge and skills.

One unanticipated finding was that teachers were enthusiastic and motivated to learn about CALL and the affordances by new technological tools, regardless of the limited availability of advanced educational technologies in their schools. However, it was the expectation of the majority of respondents to receive CALL training provided by PLSs. Teachers also thought that they could use new technologies for educational purposes, similar to their applications in everyday life. It is difficult to explain this result, but it might be related to Bax's (2003) concept of 'normalization' in integration and implementation of CALL. He asserts that normalization "is relevant to any kind of technological innovation and refers to the stage when the technology becomes invisible, embedded in everyday practice and hence "normalized"' (p. 23). This explains how CALL teacher training should ultimately empower teachers to systematically 
use new technological tools in their practices without experiencing anxiety, or even without recognizing them as technologies.

Interview results suggested that CALL is not effectively practiced among Iranian EFL teachers. Talking about this issue, an interviewee said he mainly followed the conventional methods of teaching and used CALL as a supplementary tool in a non-planned way. Another interviewee, Sima, mentioned that she did not have a general plan for running a CALL-based class, but she used technologies like digital dictionaries and the Internet to help her at some points in her teaching. The most advanced use of CALL observed in this study was one of the teacher's use of the Edmodo learning management system. Navid, who had the experience of attending a workshop on Edmodo, reported he used this tool to receive students' assignments and homework, and to provide them with feedback. He believed that Edmodo was a useful tool to receive multimedia outputs from students, and to provide them with feedback in different modalities. In the current study, no instructional design for CALL (Chapelle, 2003) provided by PLSs was reported. Hence, teachers were using CALL based on their own motivation and plans. Accordingly, it seems that teachers' self-directed learning in CALL has not effectively resulted in their systematic or normalized use of new technologies (Bax, 2003). In Hubbard and Levy's (2006) CALL teacher framework, teachers are seen as practitioners, designers, evaluators or trainers. Results from this study showed that Iranian EFL teachers take the CALL practitioner roles, without perceiving their roles as designers, evaluators or trainers of CALL. This was attributed to limitations relevant to time, funding and support from the PLSs.

As acknowledged by Arnold and Ducate (2015), "CALL teacher education overall still appears not to be adequate and effective" (p. 1). This study was motivated by similar calls for researching CALL teacher education in various contexts to address the existing challenges and suggest possible solutions. It was observed in this study that contextspecific training could play an important role in teachers' successful use of CALL. With the relatively small sample size in this study, in both qualitative and quantitative phases, caution must be applied, as the findings may not be applicable to all Iranian EFL teachers and/or PLSs. Outside the scope of this study, there could be teachers or PLSs that implement regular and systematic CALL after receiving sound training. However, one of the strengths of this study was recruiting teachers from 22 different cities all around Iran, including large (e.g., Tehran) and small (e.g., Dezful) ones. This variety can assure us that the voices of various teachers from different educational contexts have been heard, which in turn provides us with a more realistic understanding of the phenomenon. These findings have important implications for developing appropriate and effective CALL teacher training programs that meet the needs of Iranian EFL teachers and students. This is an important issue for potential research. In the future investigations, it might be possible to conduct experimental research on various types of CALL training and observe their short- and long-term effects on teachers' use of new technologies.

\section{CONCLUSION}

This study investigated the status of CALL teacher training in Iran and its effect on EFL teachers' use of educational technologies. The findings revealed that the amount and types of current trainings have not resulted in teachers' normalized (Bax, 2003) used of new technologies. It became evident that principally teachers were self-trained, in the absence of formal CALL training provided by the PLSs and TESOL courses at university level (Kessler, 2006). Teachers identified workshops as the most effective way of learning about CALL, however, only a small minority experienced this training medium. The evidence from this study suggests that CALL teacher training is not appropriately provided in the Iranian PLSs and/or universities, which calls for considerable changes in these sectors. Self-edification and lack of instructional design seemed to result in sporadic and non-systematic use of CALL among Iranian teachers. It is recommended that PLSs should provide context-specific CALL training to promote the regular and systematic use of technologies by teachers (Herna'ndez-Ramos, 2005). The current findings add to a growing body of literature on CALL teacher education. This topic is understudied in the Iranian context, and it is recommended to conduct further studies in order to gain an in-depth understanding of the issues. The implementation of gradual and systematic changes into current EFL teacher training courses is critical, for the success of CALL strongly relies on language teacher education (Hubbard, 2008).

\section{REFERENCES}

[1] Arnold, N., \& Ducate, L. (2015). Contextualized views of practices and competencies in CALL teacher education research. Language Learning \& Technology, 19(1), 1-9.

[2] Bax, S. (2003). CALL: Past, present and future. System, 31(1), 13-28.

[3] Blake, R. J. (2013). Brave new digital classroom: Technology and foreign language learning. USA: Georgetown University Press.

[4] Braun, V., \& Clarke, V. (2006). Using thematic analysis in psychology. Qualitative research in psychology, 3(2), 77-101.

[5] Burns, M., Menchaca, M., \& Dimock, V. (2002). Applying technology to restructuring and learning. Paper presented at the Proceedings of the Conference on Computer Support for Collaborative Learning: Foundations for a CSCL Community.

[6] Chao, C. c. (2015). Rethinking transfer: Learning from call teacher education as consequential transition. Language Learning and Technology, 19(1), 102-118. 
[7] Chapelle, C. (2006). L2 vocabulary acquisition theory. In Chalhoub-Deville, M., Chapelle, C. A., \& Duff, P. A. (Eds.), Inference and generalizability in applied linguistics (pp. 47-64). Amsterdam: John Benjamins Publishing.

[8] Chun, D. M. (2016). The role of technology in SLA research. Language Learning \& Technology, 20(2), 98-115.

[9] Cohen, L., Manion, L., \& Morrison, K. (2013). Research methods in education. London: Routledge.

[10] Corbin, J., \& Strauss, A. (2008). Basics of qualitative research: techniques and procedures for developing grounded theory. California: Sage Publications, Inc.

[11] Cuban, L. (2009). Oversold and underused. USA: Harvard University Press.

[12] Cutrim Schmid, E., \& Hegelheimer, V. (2014). Collaborative research projects in the technology-enhanced language classroom: Pre-service and in-service teachers exchange knowledge about technology. ReCALL, 26(3), 315-332.

[13] Dooly, M. (2009). New competencies in a new era? Examining the impact of a teacher training project. ReCALL, 21(03), 352369.

[14] Egbert, J. L., \& Petrie, G. M. (2006). CALL research perspectives. London: Routledge.

[15] Egbert, J., Paulus, T. M., \& Nakamichi, Y. (2002). The impact of CALL instruction on classroom computer use: A foundation for rethinking technology in teacher education. Language Learning \& Technology, 6(3), 108-126.

[16] Fatemi Jahromi, S. A., \& Salimi, F. (2013). Exploring the human element of computer-assisted language learning: An Iranian context. Computer Assisted Language Learning, 26(2), 158-176.

[17] Foomani, E. M., \& Hedayati, M. (2016). A seamless learning design for mobile assisted language learning: An Iranian context. English Language Teaching, 9(5), 206-213.

[18] Ghaemi, F., \& Ebrahimi, F. (2015). The impact of implementing computer games and motor activity on early EFL vocabulary achievement. Theory and Practice in Language Studies, 5(6), 1216-1225.

[19] Godwin-Jones, R. (2016). Emerging technologies, looking back and ahead: 20 years of technologies for language learning. Language Learning \& Technology, 20(2), 5-12.

[20] Godwin-Jones, R. (2015). The evolving roles of language teachers: Trained coders, local researchers, global citizens. Language Learning \& Technology, 19(1), 10-22.

[21] Golonka, E. M., Bowles, A. R., Frank, V. M., Richardson, D. L., \& Freynik, S. (2014). Technologies for foreign language learning: a review of technology types and their effectiveness. Computer Assisted Language Learning, 27(1), 70-105.

[22] Gonzalez, D., \& Louis, R. S. (2013). CALL in low-tech contexts. In Thomas, M., Reinders, H., \& Warschauer, M. (Eds.). Contemporary Computer-Assisted Language Learning (pp. 217-241), UK: Bloomsbury Academic.

[23] Guichon, N., \& Hauck, M. (2011). Editorial: Teacher education research in CALL and CMC: more in demand than ever. ReCALL, 23(03), 187-199.

[24] Hampel, R. (2009). Training teachers for the multimedia age: Developing teacher expertise to enhance online learner interaction and collaboration. International Journal of Innovation in Language Learning and Teaching, 3(1), 35-50.

[25] Hedayati, H., \& Marandi, S. S. (2014). Iranian EFL teachers' perceptions of the difficulties of implementing CALL. ReCALL, 26(3), 298-314.

[26] Hedayati, M., \& Foomani, E. M. (2015). Learning style and task performance in synchronous Computer-Mediated Communication: A case study of Iranian EFL learners. Journal of Educational Technology \& Society, 18(4), 344-356.

[27] Herna' ndez-Ramos, P. (2005). If not here, where? Understanding teachers' use of technology in Silicon Valley schools. Journal of Research on Technology in Education, 38(1), 39-64.

[28] Hong, K. H. (2010). CALL teacher education as an impetus for L2 teachers in integrating technology. ReCALL, 22(1), 53-69.

[29] Hord, S. M. (2009). Professional learning communities. Journal of Staff Development, 30(1), 40-43.

[30] Hubbard, P. (2008). CALL and the future of language teacher education. Calico Journal, 25(2), 175-188.

[31] Hubbard, P., \& Levy, M. (2006). Teacher education in CALL (Vol. 14). Amsterdam: John Benjamins Publishing.

[32] Kessler, G. (2006). Assessing CALL teacher training: What are we doing and what could we do better. In Hubbard, P., \& Levy, M. (Eds.). Teacher education in CALL (pp. 23-42). Amsterdam: John Benjamins Publishing.

[33] Khodaparast, F., \& Ghafournia, N. (2015). The Effect of asynchronous/synchronous approaches on English vocabulary achievement: A study of Iranian EFL learners. English Language Teaching, 8(4), 117-127.

[34] Khoshsima, H., \& Toroujeni, S. M. H. (2017). Context in English language teaching program: differentiating between Iranian public schools and private institutes. Journal of English Language Teaching and Linguistics, 2(1), 13-36.

[35] Kozlova, I., \& Priven, D. (2015). ESL teacher training in 3D virtual worlds. Language Learning \& Technology, 19(1), 83-101.

[36] Kumaravadivelu, B. (2002). Beyond methods: Macrostrategies for language teaching. USA: Yale University Press.

[37] Lamy, M.-N., \& Hampel, R. (2007). Online communication in language learning and teaching. UK: Palgrave Macmillan Basingstoke.

[38] Lee, L. (2016). Autonomous learning through task-based instruction in fully online language courses. Language Learning \& Technology, 20(2), 81-97.

[39] Little, D. (2007). Language learner autonomy: Some fundamental considerations revisited. International Journal of Innovation in Language Learning and Teaching, 1(1), 14-29.

[40] Liu, M. H., \& Kleinsasser, R. C. (2015). Exploring EFL teachers' CALL knowledge and competencies: In-service program perspectives. Language Learning \& Technology, 19(1), 119-138.

[41] McNeil, L. (2013). Exploring the relationship between situated activity and CALL learning in teacher education. ReCALL, 25(02), 215-232.

[42] Mohammadian Haghighi, F., \& Norton, B. (2017). The role of English language institutes in Iran. TESOL Quarterly, 51(2), 428-438.

[43] Motteram, G., Slaouti, D., \& Onat-Stelma, Z. (2013). Second language teacher education for CALL: An alignment of theory and practice'. In Thomas, M, Reinders, H and Warschauer, M (2013) Contemporary Computer-Assisted Language Learning. UK: Bloomsbury Academic.

[44] Mumtaz, S. (2000). Factors affecting teachers' use of information and communications technology: a review of the literature. Journal of information technology for teacher education, 9(3), 319-342. 
[45] Nia, S. F., \& Marandi, S. (2014). Digital literacy and netiquette: Awareness and perception in EFL learning context. In $C A L L$ Design: Principles and Practice-Proceedings of the 2014 EUROCALL Conference, Groningen, The Netherlands (Vol. 77).

[46] O'Dowd, R. (2015). Supporting in-Service language educators in learning to telecollaborate. Language Learning \& Technology, 19(1), 63-82.

[47] Patton, M. (2002). Qualitative Research and Evaluation Methods. London: Sage.

[48] Peeraer, J., \& Petegem, P. V. (2010). Factors influencing integration of ICT in higher education in Vietnam. Proceedings of Global Learn Asia Pacific, 916-924.

[49] Shin, S.-K. (2015). Teaching critical, ethical, and safe use of ICT to teachers. Language Learning \& Technology, 19(1), pp 181-197.

[50] Tai, S.-J. D. (2015). From TPACK-in-action workshops to classrooms: CALL competency developed and integrated. Language Learning \& Technology, 19(1), 139-164.

[51] Wach, A. (2015). Promoting pre-service teachers' reflections through a cross-cultural Keypal project. Language Learning \& Technology, 19(1), 34-45.

[52] Wang, Y., Chen, N.-S., \& Levy, M. (2010). Teacher training in a synchronous cyber face-to-face classroom: Characterizing and supporting the online teachers' learning process. Computer Assisted Language Learning, 23(4), 277-293.

[53] Wildner, S. (2013). Technology integration into preservice foreign language teacher education programs. Calico Journal, 17(2), 223-250.

[54] Zare-Ee, A. (2011). University teachers' views on the use of information communication technologies in teaching and research. The Turkish Online Journal of Educational Technology, 10(3). 318-327

[55] Zhao, Y., \& Cziko, G. A. (2001). Teacher adoption of technology: A perceptual control theory perspective. Journal of technology and teacher education, 9(1), 5-30.

Mohsen Hedayati is a PhD candidate in TESOL at the University of Tasmania, Australia. He holds a Master's degree in TEFL from University of Tehran, Iran (2014), and a Bachelor's degree in Translation Studies (2011), Iran. His current research is centered on teacher education in computer-assisted language learning. He has previously worked on discourse analysis in synchronous/asynchronous computer-mediated communication to investigate language learners' performance in relation to their individual learning styles.

Mr Hedayati is a member of Tasmanian Society for Information Technology in Education, Australian Association for the Teaching of English, and Tasmanian Association of Teachers of English to Speakers of Other Languages

Bronwyn Reynolds was awarded a PhD in Early Childhood Curriculum Design and Implementation from The University of Melbourne, Melbourne, Australia (2004); a MEd concerning The Role of an Early Childhood Educator in Children's Emerging Literacy from The University of Melbourne, Melbourne, Australia (1997); a PGrad Dip in Ed Studies (Special Education) from The University of Melbourne, Melbourne, Australia in (1994); and a BEd (Early Childhood) from the Institute of Early Childhood Development, State College of Victoria, Melbourne, Australia (1979).

She is a Senior Lecturer in the Faculty of Education at the University of Tasmania, Australia and previously held leadership and management positions at other tertiary institutions, including overseas postings. Her research interests include curriculum and leadership, positive learning environments, action research and working with undergraduate and post graduate students for whom English is an additional language (EAL) and the use of technology in learning.

Dr Reynolds is on a number of editorial boards including The Journal of Language and Translation.

Andy Bown has a PhD in Applied Linguistics from Macquarie University, Sydney, Australia (2015); an MEd in Educational Technology \& English Language Teaching from the University of Manchester, UK (2004); and a BA (Hons) in French and Linguistics from the University of York, UK (1992).

$\mathrm{He}$ is a Lecturer in Languages/TESOL at the University of Tasmania and has previously worked in the field of language teaching as a teacher, program manager and educational technology supervisor. His main research interests are second language reading and the use of technology in language learning.

Dr Bown is a member of TasTESOL and Thailand TESOL. 